\title{
How government withdrawal affects corporate social performance?
}

\author{
Farman Ullah Khan ${ }^{\mathrm{a}}$, Junrui Zhang ${ }^{b}$, Sajid Ullah ${ }^{\mathrm{c}}$, Muhammad Usman ${ }^{\mathrm{d}}$, Shahid Ali ${ }^{\mathrm{e}}$ \\ a) b) School of Management, Xi'an Jiaotong University, Xi'an, Shaanxi, P.R. CHINA. \\ c) School of Economics and Management, Xi'an University of Technology, Xi'an, Shaanxi, PR. CHINA \\ d) School of Accounting, Nanjing Audit University, Nanjing, P.R. CHINA. \\ e) School of Management Science and Engineering, Nanjing University of Information Science and Technology, Nanjing, P.R. CHINA.
}

\author{
${ }^{b}$ Corresponding author. \\ E-mail address: zhangjr@xjtu.edu.cn
}

\section{A R T I C L E I N F O}

\section{Article history:}

Received 22 October 2019

Accepted 28 July 2020

Available online 1 January 2022

\section{JEL classification:}

M1
M14
M48

M48

P2

P3

Keywords:

Corporate Social Responsibility (CSR)

Performance

Performance

Government withdrawal

Political connection

Códigos JEL:
M1
M14
M48
P2
P3

Palabras clave

Desempeño de la responsabilidad social corporativa de las empresas (RSC)

Retirada del gobierno

Privatización secundaria

Conexión política

\section{A B S T R A C T}

This study aims to investigate whether government withdrawal affect corporate social responsibility (CSR) performance, and how CEO's political connection moderates its relationship. We use sample data from Chinese listed firms over the 2010 to 2015 period to test our hypotheses. We find that decrease in state ownership through government withdrawal tends to negatively affect firms' CSR performance, but the CEO's political connection weakens its negative relationship and increases the firm's likelihood towards CSR activities. Our findings imply that firm's social engagement mainly result from high governmental involvement, and usually from political connections, because such firms are subject to close scrutiny by stakeholders and thus are more likely to improve social performance. Moreover, this research provides important implications to policy makers regarding the social outcomes of government withdrawal and the usefulness of firms political connection in developing economies like China.

(C)2022 ASEPUC. Published by EDITUM - Universidad de Murcia. This is an open access article under the CC BY-NC-ND license (http://creativecommons.org/licenses/by-nc-nd/4.0/).

\section{¿ Cómo afecta la disminución de la participación estatal a los resultados sociales} de las empresas?

R E S U M EN

Este estudio tiene como objetivo investigar si la retirada del gobierno afecta al rendimiento de la responsabilidad social corporativa (RSC), y cómo la conexión política del CEO modera su relación. Utilizamos los datos de una muestra de empresas chinas que cotizan en bolsa durante el período 2010-2015 para comprobar nuestras hipótesis. Encontramos que la disminución de la propiedad estatal a través de la retirada del gobierno tiende a afectar negativamente a los resultados de RSC de las empresas, pero la conexión política del CEO debilita su relación negativa y aumenta la probabilidad de la empresa hacia las actividades de RSC. Nuestras conclusiones implican que el compromiso social de las empresas se debe principalmente a la alta participación gubernamental, y normalmente a las conexiones políticas, porque estas empresas están sometidas a un estrecho escrutinio por parte de las partes interesadas y, por lo tanto, es más probable que mejoren sus resultados sociales. Además, esta investigación ofrece importantes implicaciones para los responsables políticos en relación con los resultados sociales de la retirada del gobierno y la utilidad de la conexión política de las empresas en economías en desarrollo como China.

(C)2022 ASEPUC. Publicado por EDITUM - Universidad de Murcia. Este es un artículo Open Access bajo la licencia CC BY-NC-ND (http://creativecommons.org/licenses/by-nc-nd/4.0/). 


\section{Introduction}

Corporate social responsibility (CSR) has become a crucial part of firms' agendas in the current competitive business environment. McWilliams \& Siegel (2000) described CSR as "actions related to social welfare, beyond the corporate financial interests, which is lawful and required by law." For instance, companies may produce products that use environmentally friendly raw materials, work closely for the interest of community stakeholders, and provide donations to charities (McCarthy et al., 2017). Social responsibilities may determine the firm's policies, because stakeholders not only need products but also want to fulfill their social needs (Jones and Stewart, 2009). However, a government is considered the best vehicle with which to fulfill the social demands of a broader society (Bai et al., 2006; Yin \& Zhang, 2012). But when governments lack resources, they induce state owned enterprises (SOEs) to engage in social projects using state ownership and political interference (Chang et al., 2015; Hu et al., 2018).

SOEs have a rich context in which CSR research can be embedded, especially in emerging economies (Xu et al., 2015). Previous studies point out that SOEs were playing significant role in social stability before market transition in emerging economies (Bai et al., 2006). So far as the pre-transition era is concerned, the SOEs' economic performance has been lackluster - specifically when SOEs were under central planning in state-influenced countries like France, China, Russia and Vietnam etc., because their primary objective was to focus on political and social-oriented objectives (Bai et al., 2006; Peng et al., 2016). In view of the less efficient performance of SOEs, governments privatized SOEs by selling state ownership in order to turn them more efficient (Meyer \& Peng, 2005; Kriauciunas \& Kale, 2006). This is especially the case with "the transition economies" such as China, which has been undergoing partial privatization since the 1990s (Peng, 2000; Fan et al., 2007). Yet, from an institutionalization standpoint, the China Securities Regulatory Commission (CSRC) inaugurated the split share structure reform in 2005 that opened the gates to secondary privatization and removed the legal barriers to sell state shares to private investors (Guthrie, 2012; Jiang \& Kim, 2015). Consequently, secondary privatization changed the ownership structure, and even reduced the ratio of state-owned firms in China from 65.50 percent in 2006 to 35.28 percent in 2015 (Usman et al., 2018).

The aim of this study is to explore how government withdrawal matters for firms' social priorities. Is reduction in state ownership favorable in respect of corporate social performance? Our research question is particularly motivated by the repercussions of privatization reforms. For instance, prior literature documented that privatization reforms introduced competitive environment to the new start-ups in developed and emerging economies (Megginson \& Netter, 2001; Gupta, 2005; Liao et al., 2014) as they newly joined the rules of game "market-based competition" (Mutlu et al., 2015). Particularly, the government withdrawal via privatization freed firms from the influence of controlling shareholders (state owners) and government control (Naughton, 2007; Cuervo-Cazurra et al., 2014; Tang et al., 2018). Moreover, firms employed more market oriented managers after government withdrawal, and hence, their goals became more closely linked with profit maximization (Peng et al., 2016; Wu et al., 2016). Extending this logic, we predict that government withdrawal dilutes government substantial influence over firms that may reduce the firms' likelihood toward CSR.
Next, we improve this debate on government withdrawal and firms' social performance by investigating the moderating role of CEOs' political connection. Generally, political connections allow government to have a tight grip on firms' policies. As previous studies have established that most of firms' executives get appointed by a political setup pave way for government to exert influence over such firms (Boubakri et al., 2013; Tu et al., 2013; He \& Fang, 2016). Second, politically connected executives can approach important information related to social policies, and make decisions about social investment using political power (Zhang, 2017). Besides, such executives comply with government's policies (i.e., social policies) as they receive preferential treatment from government (Ma \& Parish, 2006). In a nutshell, the nexus between politically connected executives and government motivate us to examine whether executives' connection facilitate residual state owners in setting social objectives or not.

In order to examine these predictions, the world's fastest emerging economy-China- necessitate our attention due to its unique institutional setting and ownership structure, and its radical privatization movement. Using listed firms' data during period of 2010 to 2015, we find government withdrawal has negative association with firms' CSR performance. By testing moderating effect of political connection, we find that politically connected executives weaken its negative link of government withdrawal with CSR. These findings suggest that the residual state owners may mitigate issues regarding social welfare by appointing political bureaucrats on firms' executive level.

Our paper makes several contributions to the prior literature. First, beyond the existing literature on privatization movement throughout the world, which has largely focused how governemnt withdrawal improves firms' financial efficiency (Gupta, 2005; Fan et al., 2007; Borisova and Megginson, 2011; Ben-Nasr et al., 2015; Megginson, 2017; Chen et al., 2018), we investigate its effect on the firms' social performance. Second, formerly scholars have devoted their attention to examine social effects of state ownership and private ownership (Bai et al., 2006; Li \& Zhang, 2010; Cumming et al., 2016). However, we go a step further by investigating social consequences of government withdrawal. Third, government withdrawal is generally associated with reduction in state ownership and increase in private ownership level (Gupta, 2005). We thus contribute to the shareholder theory of CSR that explains the responsibilities of private shareholders, by investigating whether sale of state ownership to private owners affects corporate social responsibilities. Fourth, we contribute to the debate on political connection that it provides indirect means of involvement to government to affect a firm's vital decisions in context of state divestiture (Fan et al., 2007; Boubakri et al., 2008; Boubakri et al., 2009; Boubakri et al., 2013, Chen et al., 2018) by providing evidence that executives' political relations can significantly moderate the firms' decisions related to CSR even if the state owners decreases its ownership level in firms.

The rest of the paper is structured as follows. Section 2 develops the hypotheses. Section 3 introduces the data and the sample and describes the variables and the research model. Section 4 discusses the results, and section 5 highlights the conclusion.

\section{Literature and Hypotheses development}

The public finance scholars define state enterprises as social entities whose aim is to work for social development 
(Shapiro \& Willig, 1990), which private enterprises fail to do. Under the general view of welfare-maximization, state firms may contribute more in social activities than other firms do. But in reality, state officials often use state firms for their vested interests (Shleifer, 1998). For instance, Boycko et al. (1993) demonstrate that government always engage SOEs to promote regional development and employment for political scoring rather than to improve firms' performance. Thus, they become inefficient public enterprises.

To mitigate concerns of inefficiency, privatization reforms, which transfer both asset rights and control from state to private owners have taken place worldwide over the last few decades (Boubakri et al., 2009). This ownership change is accompanied by firms' change in priorities such as focusing more on economic goals than political goals (Megginson \& Netter, 2001; Megginson, 2017). Prior research studies document that after state divestiture, the economic performance of firm improves significantly (Boubakri \& Cosset, 1998; DŚouza \& Megginson, 1999; Boubakri et al., 2005; Gupta, 2005; Bai et al., 2009). But the recent studies, however, overlooked its impact on the firms' social performance that needs scholarly attention. Therefore, we next propose the study hypotheses on outcomes of government withdrawal with regard to corporate social performance.

\subsection{Government withdrawal}

Government withdrawal reduces state ownership in a firm that is strongly opposed by scholars who view it as favorable to private and market-oriented investors, but detrimental to stakeholders, such as employees, minor shareholders, and society at large. This contradictory view is supported by reliable evidence of decrease in ratio of employment (Chong \& López-de-Silanes, 2005) as well as increased poverty level after transferring state share and control to private owners (Bayliss, 2002; Birdsall \& Nellis, 2003). Generally, these concerns are demonstrated against privatization in developing economies, such as Thailand, Italy, Mexico, and Greece. Likewise, Bortolotti et al. (2002) investigate the global telecommunication industry (in 25 countries) and find that government divestiture is beneficial in terms of a firm's output, investment, profitability and operating efficiency, while detrimental in terms of employment. In brief, this suggests that government withdrawal is supposed to be costly from broader social perspective because with government withdrawals the new private shareholders may be more induced towards economic objectives.

Specifically, the shareholder theory of CSR of Friedman (1970) advocates that firms in which state privatizes its ownership may not show better social performance as compared to their counterparts. In the light of this theory, a privatized firm's sole ethical responsibility is "maximizing market value and profitability for its shareholders", which is also claimed by the work of Marcoux (2003). According to Friedman (1970), the executives of privatized firms are employees of business owners, who have direct responsibilities to the owners, and that is to run business according to their desire, which is to generate as much profit as possible. In similar vein, Conyon \& He (2012) and Mansell (2013) argue that profit maximization comes in top priorities of managers in private ownership, and even consider CSR as wastage of resources (Jiang \& He, 2005). We therefore predict that firms where government withdrawal results in increase in private ownership would show less likelihood to socially responsible actions.

Empirically, previous trend shows that private owners are less dependent on external actors (i.e, government) for capital, hence often independent in taking corporate decision (Lee, 2009; Tang et al., 2018). In addition, the independent nature of private ownership opens up an opportunity for owners to use corporate resouces for self-interest rather than for societal interest (Udayasankar, 2008; Lee, 2009). State owners, in contrast, are in control of government institutions protecting public interest by working in comprehensive CSR programs (Scherer \& Palazzo, 2011; Tang, 2012). Most importantly, they usually experience large regulations from government authorties, which urge them to act according to society's norms (Gallo et al., 2011; Zheng et al., 2014). Furthermore, state ownership creates firms-government connection in order to gain support relative to resource endowments, which in return, regulate and pressurize firms to comply substantively in respect of fulfilling CSR motives (Oliver, 1991; Chen et al., 2014). Returning to our main focus, as state reduces its ownership, it will relinquish government's grabbing hand over firms' strategic decisions. For instance, the anecdotal evidence suggests that new private owners deemphasize any government and political motives, which prevailed under concentrated ownership of government (Boycko et al., 1996; Boubakri et al., 2013). This implies that firms will try to rationalize expenditure in pursuit of self-interest after government withdrawals, and hence will be less involved in CSR activities. However, as government ownership in firms continues to reduce, we may assume significant decline in firms' CSR performance, which leads to the following hypothesis;

Hypothesis (H1): Government withdrawal is negatively associated with firms' level of CSR performance.

\subsection{The moderating role of CEOs' political connections*}

We also explore whether CEOs' political connection affects the link between government withdrawal and firms' CSR performance. We hypothesize that CEOs' political connection weakens the link for few reasons. First, executives' networkbuilding is considered important in emerging economies such as Russia (Ledeneva \& Ledeneva, 1998; Batjargal, 2007), China (Peng, 2003; Chen et al., 2013), and India (Chacar \& Vissa, 2005) for the success of their firms. Because government takes control of critical resources in emerging economies, thus executives seek to build political connections to obtain governmental support, specifically in case of private enterprises (Dinç, 2005). For instance, Cull \& Xu (2005), and Khwaja \& Mian (2005) explains that political connections provide better opportunities to private firms of greater access to credit and chance of being bailed out if a firm is in financial distress. At the same time, connected companies would probably follow government prerequisites in the shape of fulfilling social and political liabilities.

Second, drawing this hypothesis on the basis of institutional theory that suggests that firms respond to external pressures from institutional environment where firms maneuvers, and adopt common socially accepted practices as being appropriate firm's choice" (Carpenter \& Feroz, 2001). In specific perspective of this theory, formal and informal pressure received from society as well as from central regulators can lead to coercive isomorphism that may direct firms to embrace social and environmental practices (Campbell, 2007; Weber, 2017). Likewise, the theory's supporters suggest that institutional determinants, such as government or political institution give signals in terms of legitimacy, and firms respond to those signals in the shape of increasing likelihood toward 
CSR practices (Colwell \& Joshi, 2013; Marquis \& Qian, 2014; Albertini, 2017). In conclusion, we would say that connected firms' executives and senior members will conform to norms obligated upon them by political bodies and governmental institutions.

Third, more specifically, governments use a mechanism of keeping firms politically connected for making necessary intervention (Liu et al., 2011). This is especially in case of those firms where its direct involvement becomes limited because of transferring state ownership to private shareholders. The anecdotal evidence advocates that government ownership may reduce but it will retain its control over firms through political connections (see Bortolotti \& Faccio, 2006; Boubakri et al., 2008; Boubakri et al., 2011). These leading scholars of privatization further point out that loyal politically connected executives often allow government to be involved in important decisions of connected firms. Overall, this suggests that political association will help government in making corporate policies in line with their primary objectives (societal welfare), which lead us to the following hypothesis.

Hypothesis (H2): The negative relationship between government withdrawal and CSR is weaker for firms with CEOs' political connection.

\section{Methodology}

\subsection{Sample}

The sample for our study consists of Chinese listed firms over the period of 2010 to 2015. We collect data for the study's variables from the China Stock Market and Accounting Research (CSMAR) database, which is one of the reliable sources for non-financial and financial data of listed firms. The CSR ratings are collected from Rankin's agency. We merge data collected from these databases and eliminated firm-year observations where data (on proposed variables) were missing. For instance, consistent with existing research studies of Zeng et al. (2011) and Reimsbach et al. (2018), we exclude firm-year observations of companies with $\mathrm{H}$ and B-shares, because this kind of firms are regulated by overseas rules and regulations, which makes the firm's nature and characteristics not comparable to those of Chinese A-share listed firms. In addition, firms operating in financial industries are not included in our sample because of different accounting standards, rules and laws and ownership structures. The initial sample of A-share listed firms contains 1083 firmyear observations. However, we drop 38 observations due to missing values for CSR ratings, and thus apply a final sample of 1045 firm-year observations of those firms in which government has reduced its state ownership. Our study relies on such firms because they provide information related to government withdrawal that creates basis for testing our research question.

\subsection{Measures}

\subsubsection{Dependent Variable}

Our dependent variable is CSR performance, measured as a CSR score provided by Rankins (RKS), an independent agency established in China. Rankins' rating is based on firms' social activities presented in CSR reports. RKS reviews 70 CSR indicators in CSR reports of all Chinese listed firms to compute a composite CSR score following the approach of the Global Reporting Initiative (GRI). The CSR indicators are further divided into three groups: (1) overall evaluation that covers 14 items with an average of 30 percent, which focuses on firms' CSR strategies, the extent to which stakeholder participate in socially responsible activities, innovativeness of firms' social activities, and also evaluation of external auditing; (2) technical evaluation generally focus on CSR information based on consistency, clarity and availability that covers 11 items and secures 20 percent weighted average; (3) and content evaluation covers 45 items with weighted average of 50 percent, which generally focus on the role of organizational system and leadership in implementation of CSR, and also on specific metrics for environmental, social and economic performance. A firm's total CSR score is calculated by the weighted average of scores of the above three sub-groups. The rating score ranges from 0 to a high of 100 that reflects the corporate social performance in terms of the firm's contribution in CSR. Rankin's CSR dataset has been validated and published in well-known journals by previous researchers such as Luo et al. (2013), Marquis \& Qian (2014), Zheng et al. (2014) and Lau et al. (2016) using Chinese context.

\subsubsection{Independent Variables}

Our main variable of interest is government withdrawal indicating reduction in state ownership by selling state ownership to private investors (Chen et al., 2018). Following the approach of Gupta (2005), we use a continuous variable measurement for government withdrawal (Reduction), indicating percentage of shares reduced by government through private sale that captures the degree of government withdrawal in a firm and its consequences.

\subsubsection{Moderating Variable}

We use political connection for estimating its moderating effect in our study. According to the definition of Fan et al. (2007), firms are considered politically connected when any of its senior member is currently or formerly serving as government bureaucrat (an officer of the military or state or local level government). Similar to He et al. (2014), Cao et al. (2018) and Li et al. (2019), we use CEO's political connection (PC) because CEO is considered more influential when making important strategic decisions. However, PC is measured by a dummy variable coding 1 if the CEO of a firm is a member of the National People's Congress (NPC) or the Chinese People's Political Consultative Conference (CPPCC), and 0 otherwise.

\subsubsection{Control Variables}

To confirm that the models' results are not affected by firm heterogeneity, we include several firm-level characteristics to control their impact on CSR. For example, research has suggested that board characteristics may affect the flow of information and corporate policies including social responsibilities (Lau et al., 2016), so we control for independent director (Ind-D), measured as taking their percentage; and CEO duality (Duality), which we consider 1 when CEO also maintain board chair and 0 otherwise (Usman et al., 2018).

Since firms' financial indicators may influence their social interests (Legendre \& Coderre, 2013; Lopatta et al., 2017), so we control for return on assets (ROA), calculated as net profit to total assets, and Tobin's Q (TobinQ), calculated as the firm's market value to total assets. Previously noted that older firms tend to participate less to social responsibilities than younger firms do (Marquis \& Qian, 2014), thus our 
study add firm age calculated as total years since the firm was established. Moreover, since larger firms tend to get more media attention than smaller firms do (Zheng \& Zhang, 2016), we therefore add size of firms (Size) which is taken through natural log of total assets, and growth (Grow), estimated by change in total assets. We also add the leverage ratio (Lev), total debt to total assets, and growth opportunities (GrowOp), taken as the book to market value of shareholders' equity (Khan et al., 2019). For the detail description of variables, (see Table 1).

Table 1. Variables definition and details

\begin{tabular}{|c|c|}
\hline Variable & Details \\
\hline CSR & $\begin{array}{l}\text { CSR is calculated by ratings score provided by } \\
\text { Rankins. }\end{array}$ \\
\hline Reduction & $\begin{array}{l}\text { Reduction represents government withdrawal and is } \\
\text { continuous variable indicating percentage of shares } \\
\text { reduced by state owners by selling it to private } \\
\text { investors, which varies } 0 \text { to } 100 \text { percent. }\end{array}$ \\
\hline PC & $\begin{array}{l}\text { PC is a dummy variable equal } 1 \text { if CEO is politically } \\
\text { connected, and } 0 \text { otherwise. }\end{array}$ \\
\hline Ind_D & $\begin{array}{l}\text { It indicates the number of independent directors } \\
\text { serving on firms' board. }\end{array}$ \\
\hline Duality & $\begin{array}{l}\text { It equals to } 1 \text { if the CEO also serves as the board chair } \\
\text { and } 0 \text { otherwise. }\end{array}$ \\
\hline ROA & $\begin{array}{l}\text { ROA indicates the profitability status of a firm which } \\
\text { is measured as net profit to total assets. }\end{array}$ \\
\hline TobinQ & $\begin{array}{l}\text { Tobin's Q is measured as the firm' market value to } \\
\text { total assets. }\end{array}$ \\
\hline Size & $\begin{array}{l}\text { Size of a firm is calculated as natural log of corporate } \\
\text { assets. }\end{array}$ \\
\hline Age & $\begin{array}{l}\text { Age of a firm is calculated as total years since the firm } \\
\text { was established. }\end{array}$ \\
\hline Grow & $\begin{array}{l}\text { Grow indicates forms' growth measured as change in } \\
\text { total assets. }\end{array}$ \\
\hline Lev & Leverage indicates total debt to total assets. \\
\hline GrowOp & $\begin{array}{l}\text { Growth opportunities is calculated as ratio of book to } \\
\text { market value of shareholders' equity. }\end{array}$ \\
\hline
\end{tabular}

\subsection{Summary statistics and Pairwise Correlation}

Table 2 provides descriptive statistics of our study's variables considered for analysis. Our summary statistics indicates that CSR scores ranges between 90.84 and 0, with an average of 31.142 along with standard deviation about 20.851, indicating considerable variations in CSR ratings across sample firms. This statistic further shows that mean of Reduction is 16.631 , which indicates that a firm has reduced state ownership through government withdrawal with an average of 16.631 percent. Moreover, the mean value for PC is 0.127 which implies that $12.7 \%$ of sample firms correspond to CEOs' political connections.

Table 2. Descriptive Statistics

\begin{tabular}{lrrrrr}
\hline Variable & Obs & Mean & Std. Dev. & Min & Max \\
\hline CSR & 1045 & 31.142 & 20.851 & 0.000 & 90.840 \\
Reduction & 1045 & 16.631 & 26.093 & 0.000 & 100.000 \\
PC & 1009 & 0.127 & 0.333 & 0.000 & 1.000 \\
Ind_D & 1045 & 4.157 & 1.394 & 2.000 & 13.000 \\
Duality & 1045 & 0.131 & 0.338 & 0.000 & 1.000 \\
ROA & 1045 & 0.042 & 0.071 & -0.769 & 1.090 \\
TobinQ & 1045 & 2.564 & 2.128 & 0.871 & 24.495 \\
Size & 1045 & 3.116 & 0.063 & 2.942 & 3.332 \\
Age & 1045 & 13.322 & 5.228 & 1.000 & 26.000 \\
Grow & 1045 & 1.042 & 2.276 & -4.344 & 45.120 \\
Lev & 1045 & 0.511 & 0.199 & 0.010 & 1.650 \\
GrowOp & 1045 & 1.073 & 0.990 & 0.042 & 8.651 \\
\hline
\end{tabular}

To detect potential multicollinearity issue among variables, we estimate variance inflation factor (VIF) test for which the results are reported in Table 3 . The maximum value of VIF is obtained for firm size (2.45) and the mean VIF is 2.80. Taken together, all the variables' VIF values are below the standard value $(>5)$, which provide evidence of a low variance inflation factor. Therefore, we believe that there is no multicollinearity issue among the variables. In addition, Table 3 shows results of pairwise correlation between the estimated variables. We find that our main independent variable government withdrawal (Reduction) is negatively related to CSR, recommend that firms having reduced state ownership following secondary privatization exhibit lower CSR performance. Furthermore, the coefficients of the independent variables are all less than 0.60 , so variables highlighted in correlation matrix not highly correlated with each other.

\subsection{Model Selection}

Given the change in corporate ownership structure following privatization of government ownership, a panel framework is more appropriate to use, which can better help in shedding light on link between government withdrawal and CSR performance. We employ the regression models using the ordinary least squares (OLS) and cluster of standard errors at firms' level, as consistent with prior studies (Claessens et al., 2008; Boubakri et al., 2011; Khan et al., 2019). To estimate H2, we apply same model for finding moderating

Table 3. VIF and Pairwise correlation

\begin{tabular}{|c|c|c|c|c|c|c|c|c|c|c|c|c|c|}
\hline Variables & VIF & (1) & $(2)$ & (3) & (4) & (5) & (6) & (7) & (8) & (9) & (10) & (11) & $(12)$ \\
\hline (1) CSR & --- & 1.000 & & & & & & & & & & & \\
\hline (2) Reduction & 1.220 & $-0.100 *$ & 1.000 & & & & & & & & & & \\
\hline (3) PC & 1.120 & $0.127^{*}$ & $0.055^{\star}$ & 1.000 & & & & & & & & & \\
\hline (4) Ind_D & 1.160 & $0.045^{*}$ & 0.001 & -0.002 & 1.000 & & & & & & & & \\
\hline (5) Duality & 1.090 & -0.024 & $0.082^{*}$ & $0.191 *$ & -0.038 & 1.000 & & & & & & & \\
\hline (6) $\mathrm{ROA}$ & 1.410 & $0.208 *$ & $0.087^{*}$ & $0.074 *$ & 0.022 & $0.071 *$ & 1.000 & & & & & & \\
\hline (7) TobinQ & 1.560 & $-0.152^{*}$ & $0.175^{*}$ & -0.046 & -0.024 & $0.070 *$ & $0.161 *$ & 1.000 & & & & & \\
\hline (8) Size & 2.450 & $0.386^{*}$ & $-0.175^{*}$ & $0.079 *$ & $0.242^{*}$ & -0.054 & -0.020 & $-0.461 *$ & 1.000 & & & & \\
\hline (9) Age & 1.210 & $-0.036^{*}$ & $0.111^{*}$ & -0.002 & $0.060 *$ & 0.002 & $-0.088 *$ & 0.014 & $0.085^{*}$ & 1.000 & & & \\
\hline (10) Grow & 1.170 & 0.015 & $0.230 *$ & 0.031 & $0.093^{*}$ & -0.005 & $0.244 *$ & 0.055 & -0.009 & -0.001 & 1.000 & & \\
\hline (11) Lev & 1.790 & -0.039 & $0.009 *$ & -0.025 & $0.064 *$ & $0.039 *$ & $-0.376^{*}$ & $-0.290 *$ & $0.382 *$ & $0.130 *$ & $-0.086 *$ & 1.000 & \\
\hline (12) GrowOp & 2.280 & $0.165^{*}$ & -0.049 & 0.014 & $0.084^{*}$ & -0.010 & $-0.206^{*}$ & $-0.464^{*}$ & $0.508 *$ & $0.082 *$ & $-0.063 *$ & $0.509 *$ & 1.000 \\
\hline
\end{tabular}

* Shows significance at the .05 level 
effect of CEOs' political connections (PC). (See Eq. (2.)

We employ the following main regression models;

$$
\begin{aligned}
& \operatorname{CSR}_{i t}=\alpha+\beta_{1} \text { Reduction }_{i t}+\beta_{2} P C_{i t}+\sum_{i=1}^{n} \beta_{n} \text { Cont }_{i t}+\varepsilon_{i t} \\
& \operatorname{CSR}_{i t}=\alpha+\beta_{1} \text { Reduction }_{i t}+\beta_{2} P C_{i t} \\
& +\beta_{3} \text { Reduction } \times P C_{i t}+\sum_{i=1}^{n} \beta_{n} \text { Cont }_{i t}+\varepsilon_{i t}
\end{aligned}
$$

where CSR is social responsibility performance scaled by CSR ratings; $\alpha$ is a constant effect; Reduction represents government withdrawal and is a continuous variable indicating percentage reduction in state ownership; $P C$ is political associations of executives; Reduction OEPC is the interaction between government withdrawal and political connections; Cont refers various firm-related control variables; the subscript it is firm $i$ observed in year $t$; and $\varepsilon$ is an error term that refers to the effect of other factors that are not covered in this study.

\section{Results and Discussion}

\subsection{Main regressions analysis}

The findings of OLS regression models for our main evidence are shown in Table 4. Model 1 demonstrate results of Hypothesis 1, which predicts that government withdrawal is negatively related to the level of firms' CSR performance. The result of Model 1 support H1 because the coefficient of Reduction $(\beta=-0.047, \mathrm{p}<.05)$ is negative and significant at $5 \%$ significance level, suggesting that government withdrawal through private sale decreases the firms' likelihood toward CSR, and thus hinders firms' CSR performance. The possible explanation for this relationship can be the changing social priorities of firms with government withdrawal. Because prior research claims that government withdrawal freed firms from state control and hence their objectives became profit-oriented (Peng et al., 2016; Wu et al., 2016). Moreover, government is considered guardian of society, and privatization of government ownership is detrimental to society (Birdsall \& Nellis, 2003; Chong \& López-de-Silanes, 2005), because government owners mostly focus on socially responsible projects but the objectives of private owners largely rely on profit maximization (Bai et al., 2006). Since our findings imply that government withdrawal reduces state ownership and increases private ownership that may rationalize firms' investment in pursuit of economic benefits (profit generations) rather than social objectives.

Turning to the second hypothesis, we measure the interaction effect of CEOs' political connection in Model 2. To do so, we explore that interaction variable Reduction $x$ PC $(\beta=0.094, \mathrm{p}<.10)$ is positive with $10 \%$ of significance level. Since, this confirms our second hypothesis (H2) and shows that CEOs' political association weakens negative link among government withdrawal (Reduction) and CSR. These results explain that CEO's political connection provide significant means to government to maintain its indirect influence over firms' strategic options including social responsibilities. Therefore, those firms are likely to support government in social welfare which have political connections even after government withdrawal. In a similar vein, because of governmental and political support, CEOs with political connections can challenge their firms' managerial thinking about supporting social policies (Chin et al., 2013), which could be one of the possible reason for our findings.
In remaining models of Table 4, we repeat our hypotheses using OLS model with clustering of standard errors by firm for initial robustness checks. Because, one of important assumption of main OLS is "the observations should be independent", which may not be fulfilled in our case because there is more than one observation from each firm in our data set, leading OLS results to be inconsistent and biased. In Model 3, we continue to find that government withdrawal (Reduction) is negative with $5 \%$ level of significance. Similarly, we find in Model 4, that interaction variable (Reduction $\mathrm{x}$ PC) is positive and significant at $10 \%$ level, as consistent with Model 2. Thus, accounting for concern of"more than single observation" using clustering estimation does not affect our main results.

Table 4 also summarizes the results for the control variables. Other than the insignificant effects of few variables such as independent director (Ind-D), firm age (Age), and firm growth (Grow), the rest of variables are influential in determining the CSR performance of listed Chinese firms. For instance, CEOs who are also board chairs (Duality) have negative relationship with CSR, because CEOs with more than single position are less likely to focus on CSR activities due to have conflicting goals (Arayssi et al., 2016). The result for ROA, Tobin's Q (TobinQ) and firm size (Size) have positive effects on CSR performance, perhaps because large, profitable and firms with strong market performance receive pressure from stakeholders to engage in CSR (Harjoto \& Jo, 2011; Zheng \& Zhang, 2016). On the other, financial leverage (Lev) and growth opportunities (GrowOp) are negatively related to CSR investment.

\begin{tabular}{|c|c|c|c|c|}
\hline \multirow[b]{2}{*}{ CSR } & \multicolumn{2}{|c|}{ OLS } & \multicolumn{2}{|c|}{ Cluster-OLS } \\
\hline & Model 1 & Model 2 & Model 3 & Model 4 \\
\hline \multirow[t]{2}{*}{ Reduction } & $-0.047^{* *}$ & $-0.058 * *$ & $-0.047 * *$ & $-0.058 * *$ \\
\hline & $(-2.040)$ & $(-2.215)$ & $(-1.988)$ & $(-2.165)$ \\
\hline \multirow[t]{2}{*}{ PC } & & $4.422 * *$ & & $4.422^{* *}$ \\
\hline & & $(2.149)$ & & (1.976) \\
\hline \multirow[t]{2}{*}{ Reduction $\times$ PC } & & $0.094 *$ & & $0.094 *$ \\
\hline & & (1.661) & & $(1.731)$ \\
\hline \multirow[t]{2}{*}{ Ind-D } & -0.112 & -0.185 & -0.112 & -0.185 \\
\hline & $(-0.267)$ & $(-0.419)$ & $(-0.245)$ & $(-0.370)$ \\
\hline \multirow[t]{2}{*}{ Duality } & $-0.723 * *$ & $-0.123 *$ & $-0.723 * *$ & $-0.123 *$ \\
\hline & $(-2.040)$ & $(-1.720)$ & $(-1.982)$ & $(-1.751)$ \\
\hline \multirow[t]{2}{*}{ ROA } & $34.041 * * *$ & $22.366^{* *}$ & $34.041 * *$ & $22.366^{*}$ \\
\hline & $(3.781)$ & (2.359) & $(2.238)$ & (1.682) \\
\hline \multirow[t]{2}{*}{ TobinQ } & $0.615^{\star}$ & $0.749 * *$ & $0.615^{* *}$ & $0.749 * *$ \\
\hline & (1.930) & $(2.221)$ & $(2.180)$ & $(2.408)$ \\
\hline \multirow[t]{2}{*}{ Age } & -0.003 & 0.059 & -0.003 & 0.059 \\
\hline & $(-0.022)$ & $(0.504)$ & $(-0.019)$ & $(0.434)$ \\
\hline \multirow[t]{2}{*}{ Size } & $189.425 * * *$ & $155.002 * * *$ & $189.425 * * *$ & $155.002 * * *$ \\
\hline & (14.123) & (13.379) & (11.912) & (11.030) \\
\hline \multirow[t]{2}{*}{ Grow } & -0.277 & -0.075 & -0.277 & -0.075 \\
\hline & $(-1.085)$ & $(-0.279)$ & $(-1.037)$ & $(-0.339)$ \\
\hline \multirow[t]{2}{*}{ Lev } & $-16.813 * * *$ & $-21.131 * * *$ & $-16.813 * * *$ & $-21.131 * * *$ \\
\hline & $(-4.635)$ & $(-5.505)$ & $(-4.020)$ & $(-5.005)$ \\
\hline \multirow[t]{2}{*}{ GrowOp } & $-2.394 * * *$ & $-1.095^{*}$ & $-2.394 * *$ & $-1.095^{*}$ \\
\hline & $(-2.916)$ & $(-1.731)$ & $(-2.529)$ & $(-1.690)$ \\
\hline \multirow[t]{2}{*}{ Constant } & $-559.008 * * *$ & $-449.076 * * *$ & $-559.008 * * *$ & $-449.076 * * *$ \\
\hline & $(-13.567)$ & $(-12.765)$ & $(-11.577)$ & $(-10.654)$ \\
\hline Observations & 1045 & 1008 & 1045 & 1008 \\
\hline R-squared & 0.316 & 0.318 & 0.316 & 0.318 \\
\hline $\begin{array}{l}\text { Industry \& Year } \\
\text { Dummies }\end{array}$ & Yes & Yes & Yes & Yes \\
\hline
\end{tabular}

Table 4. Main evidence on Government withdrawal and CSR performance

Note: Table 4 reports result for all proposed hypotheses. Reduction indicates government withdrawals through sale of ownership to private owners. T-statistics are documented in parentheses. ${ }^{* * *},{ }^{* *},{ }^{*}$ denotes significance level at 1,5 and $10 \%$, respectively. 


\subsection{Endogeneity}

One of the concerns with research on government withdrawals and privatization studies is endogeneity of privatization decisions. For instance, Megginson \& Netter (2001) suggest that government can retain inefficient state firms while may privatize the efficient first (firms having better performance with quality governance) making privatization "look good", that may arise self-selection bias that mislead the OLS results. Similar to privatization's context, we use different approaches to address relevant issues in our setting.

For instance, we apply Heckman (1979) estimation model to make our analysis further robust. To assume a firm's probability of having reductions in government ownership after secondary privatization, we first run a Probit model at first stage $^{1}$ in which we regress Reduction on corporate level variables. This approach allows us estimating the inverse ratio of Mills called as "Lambda". Moving to Heckman second stage, we include calculated Lambda in regression model with all of our study's variables. The results are presented Model 1 and 2 of Table 5, where we consistently find that government withdrawal is negatively associated with CSR, but however this relation is weaker for all the firms of politically associated executives.

Next, we use instrumental variable approach using a twostage least squares (2-SLS) regression to address endogeneity. In this method, the instrumental variable must correlate with the independent variable but not with the dependent variable. In our case, an instrumental variable should be associated with the probability of government decision to have reductions in state ownership through private sale, because endogeneity may lie in the decisions related to government withdrawal. Therefore, we use lag of the independent variable (Lag_Reduction) as an instrumental variable, and regress Reduction on Lag Reduction along with all control variables in the first stage of regression. In doing so, we find that Lag_Reduction is positively and significantly linked with $R e$ duction, confirming a good predictor. Using fitted values of the first stage for Reduction in the second stage of 2-SLS estimations in Model 3 and 4, we continue to find that Reduction is negatively associated with CSR and PC again weakens its negative relationship. Overall, these findings validate our main claim regarding corporate social performance in perspective of government withdrawals that is consistent to possible endogeneity issues. (See Table 5 for details.)

\section{Conclusion}

Prior studies on government withdrawal and privatization has devoted a lot of attention to explore its impacts associated with corporate stakeholders, such as creditors and shareholders (e.g., Boubakri et al., 2009; Borisova \& Megginson, 2011; Ben-Nasr et al., 2015; Chen et al., 2018), but overlooked its broader societal impacts. However, the general perception about the state as the guardian of society, and that government withdrawal can undermine social development, is interesting. In this backdrop, we first investigate the effect of government withdrawal on the CSR performance of Chinese firms, and then the moderating effect of CEOs' political connections on the link between government withdrawal and CSR in the context of government divestiture.

Using a sample from the first-largest emerging economyChina, we find that government withdrawal generates significantly negative impacts on firms' CSR. This is because

\footnotetext{
${ }^{1}$ The results obtained from the first stage are not reported for the sake of parsimony, and will be only available upon request.
}

Table 5. Robustness / Endogeneity tests

\begin{tabular}{|c|c|c|c|c|}
\hline \multirow[b]{2}{*}{ CSR } & \multicolumn{2}{|c|}{2 Stage-Heckman } & \multicolumn{2}{|c|}{ 2-SLS } \\
\hline & Model 1 & Model 2 & Model 3 & Model 4 \\
\hline Reduction & $\begin{array}{l}-0.046^{* *} \\
(-1.994)\end{array}$ & $\begin{array}{l}-0.063 * * \\
(-2.450)\end{array}$ & $\begin{array}{c}-12.536 * * * \\
(-2.843)\end{array}$ & $\begin{array}{c}-13.619 * * * \\
(-3.000)\end{array}$ \\
\hline PC & & $\begin{array}{c}2.902 \\
(1.415)\end{array}$ & & $\begin{array}{c}0.084 \\
(0.124)\end{array}$ \\
\hline Reduction $\times$ PC & & $\begin{array}{l}0.094 * \\
(1.671)\end{array}$ & & $\begin{array}{c}15.367 * * * \\
(3.279)\end{array}$ \\
\hline Ind-D & $\begin{array}{c}0.072 \\
(0.155)\end{array}$ & $\begin{array}{c}0.058 \\
(0.121)\end{array}$ & $\begin{array}{c}0.008 \\
(0.052)\end{array}$ & $\begin{array}{c}0.004 \\
(0.021)\end{array}$ \\
\hline Duality & $\begin{array}{c}-0.500 \\
(-0.238)\end{array}$ & $\begin{array}{c}-1.390 \\
(-0.644)\end{array}$ & $\begin{array}{c}-0.526 \\
(-1.047)\end{array}$ & $\begin{array}{l}-0.905 * \\
(-1.761)\end{array}$ \\
\hline ROA & $\begin{array}{c}33.330 * * * \\
(3.689)\end{array}$ & $\begin{array}{c}32.213 * * * \\
(3.516)\end{array}$ & $\begin{array}{c}67.913 * * * \\
(19.274)\end{array}$ & $\begin{array}{c}68.681 * * * \\
(19.156)\end{array}$ \\
\hline TobinQ & $\begin{array}{l}0.619 * \\
(1.944)\end{array}$ & $\begin{array}{l}0.700 * * \\
(2.119)\end{array}$ & $\begin{array}{c}0.071 * * * \\
(4.156)\end{array}$ & $\begin{array}{c}0.067 * * * \\
(3.904)\end{array}$ \\
\hline Age & $\begin{array}{c}-0.003 \\
(-0.027)\end{array}$ & $\begin{array}{c}0.003 \\
(0.024)\end{array}$ & $\begin{array}{c}0.038 \\
(0.849)\end{array}$ & $\begin{array}{c}0.031 \\
(0.746)\end{array}$ \\
\hline Size & $\begin{array}{c}198.760 * * * \\
(11.888)\end{array}$ & $\begin{array}{c}200.262^{* * *} \\
(11.695)\end{array}$ & $\begin{array}{c}168.560 * * * \\
(28.916)\end{array}$ & $\begin{array}{c}167.785 * * * \\
(29.410)\end{array}$ \\
\hline Grow & $\begin{array}{c}-0.209 \\
(-0.787)\end{array}$ & $\begin{array}{c}-0.120 \\
(-0.432)\end{array}$ & $\begin{array}{c}-0.796 * * * \\
(-5.614)\end{array}$ & $\begin{array}{c}-0.801 * * * \\
(-5.537)\end{array}$ \\
\hline Lev & $\begin{array}{c}-16.306 * * * \\
(-4.445)\end{array}$ & $\begin{array}{c}-15.739 * * * \\
(-4.198)\end{array}$ & $\begin{array}{c}-2.280 * * * \\
(-2.836)\end{array}$ & $\begin{array}{l}-2.069 * * \\
(-2.559)\end{array}$ \\
\hline GrowOp & $\begin{array}{c}-2.436 * * * \\
(-2.962)\end{array}$ & $\begin{array}{l}-2.510 * * * \\
(-3.019)\end{array}$ & $\begin{array}{c}-2.309 * * * \\
(-8.355)\end{array}$ & $\begin{array}{c}-2.320 * * * \\
(-8.403)\end{array}$ \\
\hline Lambda & $\begin{array}{c}4.004 \\
(0.935)\end{array}$ & $\begin{array}{c}3.725 \\
(0.855)\end{array}$ & & \\
\hline Constant & $\begin{array}{c}-595.825 * * * \\
(-10.456)\end{array}$ & $\begin{array}{c}-601.419 * * * \\
(-10.313)\end{array}$ & $\begin{array}{c}-500.146 * * * \\
(-28.106)\end{array}$ & $\begin{array}{c}-497.714^{* * *} \\
(-28.669)\end{array}$ \\
\hline Observations & 1045 & 1009 & 1045 & 1008 \\
\hline R-squared & 0.317 & 0.328 & 0.253 & 0.257 \\
\hline $\begin{array}{l}\text { Industry \& Year } \\
\text { Dummies }\end{array}$ & Yes & Yes & Yes & Yes \\
\hline
\end{tabular}

Note: T-statistics are documented in parentheses. ${ }^{* * *}, * *, *$ denotes significance level at 1,5 and $10 \%$, respectively.

government withdrawal reduces the state ownership and its influence in which case firms become more independent of state control. As a result, firms' private objectives start to prevail that can adversely affect their social goals. In addition, we find that the CEO's political connection weakens the adverse effect of government withdrawal on CSR as political connections pave way for government to maintain control over firms' strategic decisions. Overall, the results support our main propositions, and contribute to the previous debate on government divestiture and its outcomes.

Our results provide some useful implications for professionals and policy makers. First, this study provides guidance to policy makers regarding the social outcomes of government divestiture by showing that it is not advisable from broader social perspective. Second, our empirical evidence guides the regulatory authorities in emerging economies about the importance of governmental intervention in significant corporate decisions. Moreover, this study considers executives' political connection an important determinant of CSR, which may instruct policy makers. For example, improving corporate social performance in emerging markets such as China, it would be advisable to appoint bureaucrats on top executives' level.

From implementation perspective, our findings show that policy makers and regulators should abstain from "one size fits it all" social policies. Considering that firms which have undergone government withdrawals show less motivation for social welfare activities. Government, being the guardian of society should ensure the implementation of CSR strategies 
in these firms to make them socially responsible. In addition, government should address firms' resource shortages even after state divestiture, maintain necessary intervention, and treat all firms equally, to get desirable social outcomes. Finally, managers and business owners should consider mechanisms driving corporate social motives to fulfill a wider range of stakeholders' demands. For instance, in the face of uncertainty and inconstant behavior of transition economies, firms should imitate positive counterparts to rectify their own social behavior.

Our study guides the future research in several ways. First, our study tests the effect of government withdrawal on social performance. However, given the prevalence of acquisitions of state ownership across companies, it would also be interesting to investigate how these acquisitions influence CSR intensity of a particular firm. Second, future research may implement a more complex model to investigate not only the presence of political connection but also other monitoring factors, such as board independence, foreign directors on board etc., any of which could have significant interaction effects. Finally, we used a sample from China, so future research should consider firms from other countries to help in generalizing the findings of this research.

\section{Funding}

The authors gratefully acknowledge financial support from the Natural Science Foundation of China (Grant No. 71472148).

\section{Conflict of interests}

The authors declare no conflict of interests.

\section{References}

Albertini, E. (2017). What We Know About Environmental Policy: An Inductive Typology of the Research. Business Strategy and the Environment, 26(3), 277-287. https:// doi.org/10.1002/bse.1913

Arayssi, M., Dah, M., \& Jizi, M. (2016). Women on boards, sustainability reporting and firm performance. Sustainability Accounting, Management and Policy Journal, 7(3), 376-401. https://doi.org/10.1108/ SAMPJ-07-2015-0055

Bai, C. E., Lu, J., \& Tao, Z. (2009). How does privatization work in China? Journal of Comparative Economics, 37(3), 453-470. https://doi.org/10.1016/j.jce.2008.09. 006

Bai, C. E., Lu, J., \& Tao, Z. (2006). The multitask theory of state enterprise reform: Empirical evidence from China. American Economic Review, 96(2), 353-357. https://doi. org/10.1257/000282806777212125

Batjargal, B. (2007). Network triads: Transitivity, referral and venture capital decisions in China and Russia. Journal of International Business Studies, 38 (6), 9981012. https://doi.org/10.1057/palgrave.jibs.8400302

Bayliss, K. (2002). Privatization and poverty: The distributional impact of utility privatization. Annals of public and cooperative economics, 73(4), 603-625. https: //doi.org/10.1111/1467-8292.00207

Ben-Nasr, H., Boubakri, N., \& Cosset, J. C. (2015). Earnings quality in privatized firms: The role of state and foreign owners. Journal of Accounting and Public Policy,
34(4), 392-416. https://doi.org/10.1016/j.jaccpubpol. 2014.12.003

Birdsall, N., \& Nellis, J. (2003). Winners and losers: Assessing the distributional impact of privatization. World Development, 31(10), 1617-1633. https://doi.org/10. 1016/S0305-750X(03)00141-4

Borisova, G., \& Megginson, W. L. (2011). Does government ownership affect the cost of debt? Evidence from privatization. The Review of Financial Studies, 24(8), 26932737. https://doi.org/10.1093/rfs/hhq154

Bortolotti, B., D'Souza, J., Fantini, M., \& Megginson, W. L. (2002). Privatization and the sources of performance improvement in the global telecommunications industry. Telecommunications Policy, 26(5-6), 243-268. https:// doi.org/10.1016/S0308-5961(02)00013-7

Bortolotti, B., \& Faccio, M. (2006). Reluctant privatization. Nota di Lavoro, Fondazione Eni Enrico Mattei.

Boubakri, N., Cosset, J. C., \& Guedhami, O. (2009). From state to private ownership: Issues from strategic industries. Journal of Banking \& Finance, 33(2), 367-379. https://doi.org/10.1016/j.jbankfin.2008.08.012

Boubakri, N., \& Cosset, J. C. (1998). The financial and operating performance of newly privatized firms: Evidence from developing countries. The Journal of Finance, 53(3), 1081-1110. https://doi.org/10.1111/0022-1082. 00044

Boubakri, N., Cosset, J. C., \& Guedhami, O. (2005). Liberalization, corporate governance and the performance of privatized firms in developing countries. Journal of Corporate Finance, 11(5), 767-790. https://doi.org/10. 1016/j.jcorpfin.2004.05.001

Boubakri, N., Cosset, J. C., \& Guedhami, O. (2008). Privatisation in developing countries: Performance and ownership effects. Development Policy Review, 26(3), 275-308. https://doi.org/10.1111/j.1467-7679.2008.00411.x

Boubakri, N., Cosset, J. C., Guedhami, O., \& Saffar, W. (2011). The political economy of residual state ownership in privatized firms: Evidence from emerging markets. Journal of Corporate Finance, 17(2), 244-258. http: //dx.doi.org/10.1016/j.jcorpfin.2010.08.003

Boubakri, N., Cosset, J. C., \& Saffar, W. (2013). The role of state and foreign owners in corporate risk-taking: Evidence from privatization. Journal of Financial Economics, 108(3), 641-658. https://doi.org/10.1016/j.jfineco. 2012.12.007

Boycko, M., Shleifer, A., \& Vishny, R. W. (1996). A theory of privatisation. Economic Journal, 106(435), 309-319. https: / /doi.org/10.2307/2235248

Boycko, M., Shleifer, A., Vishny, R. W., Fischer, S., \& Sachs, J. D. (1993). Privatizing Russia. Brookings Papers on Economic Activity, 1993, 139-192. Available at https: //www.brookings.edu/wp-content/uploads/1993/06/ 1993b_bpea_boycko_shleifer_vishny fischer sachs.pdf

Campbell, J. L. (2007). Why would corporations behave in socially responsible ways? An institutional theory of corporate social responsibility. Academy of management Review, 32(3), 946-967. https://doi.org/10.2307/ 20159343

Cao, X., Lemmon, M., Pan, X., Qian, M., \& Tian, G. (2018). Political promotion, CEO incentives, and the relationship between pay and performance. Management Science, 65(7), 2947-2965. https://doi.org/10.1287/mnsc.2017. 2966

Carpenter, V. L., \& Feroz, E. H. (2001). Institutional theory and accounting rule choice: an analysis of four US state governments' decisions to adopt generally accepted ac- 
counting principles. Accounting, Organizations and Society, 26, 565-596.

Chacar, A., \& Vissa, B. (2005). Are emerging economies less efficient? Performance persistence and the impact of business group affiliation. Strategic Management Journal, 26(10), 933-946. https://doi.org/10.1002/smj.478

Chang, L., Li, W. J., \& Lu, X. Y. (2015). Government Engagement, Environmental Policy, and Environmental Performance: Evidence from the Most Polluting Chinese Listed Firms. Business Strategy and the Environment, 24(1), 119. https://doi.org/10.1002/bse.1802

Chen, C. C., Chen, X.-P., \& Huang, S. (2013). Chinese guanxi: An integrative review and new directions for future research. Management and Organization Review, 9(1), 167-207. https://doi.org/10.1111/more.12010

Chen, D., Li, S., Xiao, J. Z., \& Zou, H. (2014). The effect of government quality on corporate cash holdings. Journal of Corporate Finance, 27, 384-400. https://doi.org/10. 1016/j.jcorpfin.2014.05.008-

Chen, R., El Ghoul, S., Guedhami, O., \& Nash, R. (2018). State Ownership and Corporate Cash Holdings. Journal of Financial and Quantitative Analysis, 53(5), 2293-2334. https://doi.org/10.1017/S0022109018000236

Chin, M. K., Hambrick, D. C., \& Treviño, L. K. (2013). Political Ideologies of CEOs: The Influence of Executives' Values on Corporate Social Responsibility. Administrative Science Quarterly, 58(2), 197-232. https://doi.org/10. $1177 / 0001839213486984$

Chong, A., \& López-De-Silanes, F. (2005). The truth about privatization in Latin America. In , A. Chong \& F. López-De-Silanes (Eds), Privatization in Latin America: myths and reality (pp. 1-66). Washington, DC: The International Bank for Reconstruction and Development / The World Bank. Available at C:/Users/Administrador/Downloads/Privatization-inLatin-America-Myths-and-Reality.pdf

Claessens, S., Feijen, E., \& Laeven, L. (2008). Political connections and preferential access to finance: The role of campaign contributions. Journal of Financial Economics, 88(3), 554-580. https://doi.org/10.1016/j.jfineco.2006. 11.003

Colwell, S. R., \& Joshi, A. W. (2013). Corporate Ecological Responsiveness: Antecedent Effects of Institutional Pressure and Top Management Commitment and Their Impact on Organizational Performance. Business Strategy and the Environment, 22(2), 73-91. https://doi.org/10. 1002/bse.732

Conyon, M. J., \& He, L. (2012). CEO Compensation and Corporate Governance in C hina. Corporate Governance: An International Review, 20(6), 575-592. https://doi.org/ 10.1111/j.1467-8683.2012.00935.x

Cuervo-Cazurra, A., Inkpen, A., Musacchio, A., \& Ramaswamy K. (2014). Governments as owners: State-owned multinational companies. Journal of International Business Studies, 45, 919-942. https://doi.org/10.1057/jibs.2014.43

Cull, R., \& Xu, L. C. (2005). Institutions, ownership, and finance: the determinants of profit reinvestment among Chinese firms. Journal of Financial Economics, 77(1), 117-146. https://doi.org/10.1016/j.jfineco.2004.05.010

Cumming, D., Hou, W. \& Lee, E. (2016). Business Ethics and Finance in Greater China: Synthesis and Future Directions in Sustainability, CSR, and Fraud. Journal of Financial Economics, 138, 601-626. https://doi.org/10.1007/ s10551-016-3288-2

D’Souza, J., \& Megginson, W. L. (1999). The financial and op- erating performance of privatized firms during the 1990s. Journal of Finance, 54(4), 1397-1438. https://doi.org/ 10.1111/0022-1082.00150

Dinç, I. S. (2005). Politicians and banks: Political influences on government-owned banks in emerging markets. Journal of Financial Economics, 77(2), 453-479. https: //doi.org/10.1016/j.jfineco.2004.06.011

Fan, J., Wong, T., \& Zhang, T. (2007). Politically connected CEOs, corporate governance, and Post-IPO performance of China's newly partially privatized firms. Journal of Financial Economics, 84(2), 330-357. https://doi.org/ 10.1016/j.jfineco.2006.03.008

Friedman, M. (1970). The Social Responsibility of Business is to Increase Its Profits The New York Times Magazine, September 13, 1970. The New York Times Company.

Gallo, P. J., \& Christensen, L. J. (2011). Firm Size Matters: An Empirical Investigation of Organizational Size and Ownership on Sustainability-Related Behaviors. Business \& Society, 50(2), 315-349. https://doi.org/10.1177/ 0007650311398784

Gupta, N. (2005). Partial privatization and firm performance. Journal of Finance, 60(2), 987-1015. https://doi.org/10. 1111/j.1540-6261.2005.00753.x

Guthrie, D. (2012). China and globalization: The social, economic and political transformation of Chinese society. New York: Routledge.

Harjoto, M.A., \& Jo, H. (2011). Corporate Governance and CSR Nexus. Journal of Business Ethics, 100, 45-67. https: //doi.org/10.1007/s10551-011-0772-6

He, L., Wan, H., \& Zhou, X. (2014). How are political connections valued in China? Evidence from market reaction to CEO succession. International Review of Financial Analysis, 36, 141-152. https://doi.org/10.1016/j.irfa.2014. 01.011

He, L., \& Fang, J. (2016). Subnational institutional contingencies and executive pay dispersion. Asia Pacific Journal of Management, 33, 371-410. https://doi.org/10.1007/ s10490-015-9429-9

Heckman, J. J. (1979). Sample Selection Bias as a Specification Error. Econometrica, 47(1), 153-161. https: //doi.org/10.2307/1912352

Hu, Y. Y., Zhu, Y., Tucker, J., \& Hu, Y. (2018). Ownership influence and CSR disclosure in China. Accounting Research Journal, 31(1), 8-21. https://doi.org/10.1108/ ARJ-01-2017-0011

Jiang, F., \& Kim, K. A. (2015). Corporate governance in China: A modern perspective. Journal of Corporate Finance, 32, 190-216. https://doi.org/10.1016/j.jcorpfin, 2014.10.010.

Jiang, Q. J., \& He, W. (2005). A Strategic Choice of the Corporate Social Responsibility and Sustainable Development of Private Businesses Journal of Hanzhou University of Commerce, 11.

Jones, G., \& Stewart, J. (2009). New development: Accountability in public partnerships-The case of Local Strategic Partnerships. Public Money Management, 29(1), 59-64. https://doi.org/10.1080/09540960802617376

Khan, F.U. , Zhang, J. , Usman, M. , Badulescu, A. , \& Sial, M.S. (2019). Ownership Reduction in State-Owned Enterprises and Corporate Social Responsibility: Perspective from Secondary Privatization in China. Sustainability, 2019, 11, 1008. https://doi.org/10.3390/su11041008

Khwaja, A. I., \& Mian, A. (2005). Do lenders favor politically connected firms? Rent provision in an emerging financial market. The Quarterly Journal of Economics, 120(4), 1371-1411. https://doi.org/10.1162/ 
003355305775097524

Kriauciunas, A., \& KALE, P. (2006). The impact of socialist imprinting and search on resource change: A study of firms in Lithuania. Strategic Management Journal, 27(7), 659679. https://doi.org/10.1002/smj.537

Lau, C. M., Lu, Y., \& Liang, Q. (2016). Corporate Social Responsibility in China: A Corporate Governance Approach. Journal of Business Ethics, 136(1), 73-87. https://doi. org/10.1007/s10551-014-2513-0

Ledeneva, A. C., \& Ledeneva, A. V. (1998). Russia's economy of favours: Blat, networking and informal exchange. Cambridge, UK: Cambridge University Press.

Lee, P. (2009). Does Ownership Form Matter for Corporate Social Responsibility? A Longitudinal Comparison of Environmental Performance between Public, Private, and Jointventure Firms. Business and Society Review, 114(4), 435-456. https://doi.org/10.1111/j.1467-8594. 2009.00349.x

Legendre, S., \& Coderre, F. (2013). Determinants of GRI G3 Application Levels: The Case of the Fortune Global 500. Corporate Social Responsibility and Environmental Management, 20(3), 182-192. https://doi.org/10.1002/csr. 1285

Li, W. J., \& Zhang, R. (2010). Corporate Social Responsibility, Ownership Structure, and Political Interference: Evidence from China. Journal of Business Ethics, 96, 631-645. https://doi.org/10.1007/s10551-010-0488-z

Li, X., Qiao, P., \& Zhao, L. (2019). CEO media exposure, political connection and Chinese firms' stock price synchronicity. International Review of Economics \& Finance, 63, 61-75. https://doi.org/10.1016/j.iref.2018.08.006

Liao, L., Liu, B., \& Wang, H. (2014). China s secondary privatization: Perspectives from the split-share structure reform. Journal of Financial Economics, 113(3), 500-518. https://doi.org/10.1016/j.jfineco.2014.05.007

Liu, J. H., Wang, Y. P., \& Wu, L. S. (2011). The Effect of Guanxi on Audit Quality in China. Journal of Business Ethics, 103, 621-638. https://doi.org/10.1007/ s10551-011-0884-z

Lopatta, K., Jaeschke, R., \& Chen, C. (2017). Stakeholder Engagement and Corporate Social Responsibility (CSR) Performance: International Evidence. Corporate Social Responsibility and Environmental Management, 24(3), 199209. https://doi.org/10.1002/csr.1398

Luo, X., Wang, D., \& Zhang, J. (2013). State or market: Government regulation, institutional complexity, and CSR Reporting of Chinese Firms. Paper presented to Inaugural Paul R. Lawrence Conference: Connecting Rigor and Relevance in Institutional Analysis, Harvard Business School.

Ma, D., \& Parish, W. L. (2006). Tocquevillian Moments: Charitable Contributions by Chinese Private Entrepreneurs. Social Forces, 85(2), 943-964. https://doi.org/10. 1353 /sof.2007.0016

Mansell, S. (2013). Shareholder theory and Kant's 'duty of beneficence'. Journal of Business Ethics, 117(3), 583599. https://doi.org/10.1007/s10551-012-1542-9

Marcoux, A. (2003). A Fiduciary Argument Against Stakeholder Theory. Business Ethics Quarterly, 13(1), 1-24. https://doi.org/10.5840/beq20031313

Marquis, C., \& Qian, C. L. (2014). Corporate Social Responsibility Reporting in China: Symbol or Substance? Organization Science, 25(1), 127-148. https://doi.org/10. 1287 /orsc. 2013.0837

McCarthy, S., Oliver, B., \& Song, S. (2017). Corporate social responsibility and CEO confidence. Journal of Banking \& Finance, 75, 280-291. https://doi.org/10.1016/j.

\section{jbankfin.2016.11.024}

Mcwilliams, A., \& Siegel, D. (2000). Corporate social responsibility and financial performance: correlation or misspecification? Strategic Management Journal, 21(5), 603-609. https://doi.org/10.1002/(SICI) 1097-0266(200005)21:5<603::AID-SMJ101>3.0.CO;23

Megginson, W. L. (2017). Privatization, state capitalism, and state ownership of business in the 21st century. Foundations and Trendső in Finance, 11(1-2), 1-153. https: //doi.org/10.1561/0500000053

Megginson, W. L., \& Netter, J. R. (2001). From state to market: A survey of empirical studies on privatization. Journal of Economic Literature, 39(2), 321-389. https: //doi.org/10.1257/jel.39.2.321

Meyer, K. E., \& Peng, M. W. (2005). Probing theoretically into Central and Eastern Europe: Transactions, resources, and institutions. Journal of International Business Studies, 36, 600-621. https://doi.org/10.1057/palgrave.jibs. 8400167

Mutlu, C. C., Zhan, W., Peng, M. W., \& Lin, Z. J. (2015). Competing in (and out of) transition economies. Asia Pacific Journal of Management, 32, 571-596. https://doi.org/ $10.1007 /$ s10490-015-9419-y

Naughton, B. J. (2007). The Chinese economy: Transitions and growth. Cambridge, Massachusetts: The MIT Press.

Oliver, C. (1991). Strategic responses to institutional processes. Academy of Management Review 16(1), 145-179. https://doi.org/10.5465/amr.1991.4279002

Peng, M. W. (2000). Business strategies in transition economies. London, UK: Sage. http://dx.doi.org/10.4135/ 9781452231358

Peng, M. W. (2003). Institutional transitions and strategic choices. Academy of Management Review, 28(2), 275296. https://doi.org/10.5465/amr.2003.9416341

Peng, M. W., Bruton, G. D., Stan, C. V., \& Huang, Y. Y. (2016). Theories of the (state-owned) firm. Asia Pacific Journal of Management, 33, 293-317. https://doi.org/10.1007/ s10490-016-9462-3

Reimsbach, D., Braam, G., \& Wang, Z. (2018). Political embeddedness and the diffusion of corporate social responsibility practices in China: A trade-off between financial and CSR performance? Journal of Cleaner Production, 198, 1185-1197. https://doi.org/10.1016/j.jclepro. 2018.07.116

Scherer, A. G., \& Palazzo, G. (2011). The new political role of business in a globalized world: A review of a new perspective on CSR and its implications for the firm, governance, and democracy. Journal of Management Studies, 48(4), 899-931. https://doi.org/10.1111/j.1467-6486. 2010.00950.x

Shapiro, C., \& Willig, R.D. (1990). Economic Rationales for the Scope of Privatization. Oxfordshire, UK: Routledge.

Shleifer, A. (1998). State versus private ownership. Journal of Economic Perspectives, 12(4), 133-150. https://doi. org/10.1257/jep.12.4.133

Tang, B. (2012). Contemporary corporate social responsibility (CSR) in China: A case study of a Chinese compliant. Seven Pillars Institute Moral Cents, 1(2), 13-22.

Tang, P. C., Yang, S. W., \& Boehe, D. (2018). Ownership and corporate social performance in China: Why geographic remoteness matters. Journal of Cleaner Production, 197(1), 1284-1295. https://doi.org/10.1016/ j.jclepro.2018.06.288

Tu, G. Q., Lin, B. X., \& Liu, F. (2013). Political connections and privatization: Evidence from China. Journal 
of Accounting and Public Policy, 32(2), 114-135. https: //doi.org/10.1016/j.jaccpubpol.2012.10.002

Udayasankar, K. (2008). Corporate social responsibility and firm size. Journal of Business Ethics, 83(2), 167-175. https://doi.org/10.1007/s10551-007-9609-8

Usman, M., Zhang, J., Wang, F., Sun, J., \& Makki, M.A.M. (2018). Gender diversity in compensation committees and CEO pay: evidence from China. Management Decision, 56(5), 1065-1087. https://doi.org/10.1108/ MD-09-2017-0815

Weber, O. (2017). Corporate sustainability and financial performance of Chinese banks. Sustainability Accounting, Management and Policy Journal, 8(3), 358-385. https: //doi.org/10.1108/SAMPJ-09-2016-0066

Wu, W., Johan, S. A., \& Rui, O. M. (2016). Institutional investors, political connections, and the incidence of regulatory enforcement against corporate fraud. Journal of Business Ethics, 134(4), 709-726. https://doi.org/10. 1007/s10551-014-2392-4

Xu, E., Yang, H., Quan, J.M., \& Lu, Y. (2015). Organizational slack and corporate social performance: Empirical evidence from China's public firms. Asia Pacific Journal of Management, 32, 181-198. https://doi.org/10.1007/ s10490-014-9401-0

Yin, J., \& Zhang, Y. (2012). Institutional Dynamics and Corporate Social Responsibility (CSR) in an Emerging Country Context: Evidence from China. Journal of Business Ethics, 111, 301-316. https://doi.org/10.1007/ s10551-012-1243-4

Zeng, S. X., Xu, X. D., Yin, H. T., \& Tam, C. M. (2011). Factors that Drive Chinese Listed Companies in Voluntary Disclosure of Environmental Information. Journal of Business Ethics, 109, 309-321. https://doi.org/10.1007/ s10551-011-1129-X

Zhang, C. (2017). Political connections and corporate environmental responsibility: Adopting or escaping? Energy Economics, 68, 539-547. https://doi.org/10.1016/ j.eneco.2017.10.036

Zheng, H., \& Zhang, Y. (2016). Do SOEs outperform private enterprises in CSR? Evidence from China. Chinese Management Studies, 10, 435-457. https://doi.org/10.1108/ CMS-10-2015-0225

Zheng, L., Balsara, N., \& Huang, H. (2014). Regulatory pressure, blockholders and corporate social responsibility (CSR) disclosures in China. Social Responsibility Journal, 10(2), 226-245. https://doi.org/10.1108/ SRJ-08-2012-0102 